\title{
Teacher Training Scaffolding Type to Improve Teacher's Ability in Developing Guided Inquiry Practical Worksheet
}

\author{
Abdul Rosid \\ ${ }^{1}$ Sekolah Pascasarjana, Universitas Pendidikan Indonesia \\ abdulrosid.duchie@gmail.com
}

\author{
Yayan Sunarya, Mulyati Arifin \\ Departemen Pendidikan Kimia FPMIPA UPI Bandung
}

\begin{abstract}
Generally, a teacher training is still ineffective and has many weaknesses in its implementation. The main objective of a teacher training is to improve teachers' abilities and skills in teaching, so as to prepare students for competition in the millennial century. In chemistry learning teachers must be able to stimulate all initiatives, creativity and scientific attitudes through guided inquiry-based laboratory activities. The purpose of this study was to measure the effectiveness of a teacher training in improving the ability to develop guided inquiry lab worksheets to achieve students' understanding and literacy. The training involved 26 chemistry teachers who teach in Karawang West Java. The method applied in this study was multi-method, both quantitative and qualitative with multi-design. The results indicate that the teacher's response to training materials and training methods is very strong based on the results of the pretest and post-test. Increased ability of teachers in inquiry is classified as medium category. In general, the teacher's response to the training showed a very positive response especially to the topic of practical evaluation. Some teachers demonstrated their ability to design guided inquiry-based lab worksheets mainly related to contextual phenomena, including the effect of vinegar acid concentration on baking soda decomposition reactions, and the effect of fertilizer concentrations on grain sprout growth.
\end{abstract}

Keywords-guided inquiry; LKS; rate Of reaction; scaffolding; scientific literacy; training.

\section{INTRODUCTION}

A teacher must have pedagogical competence, personal competence, social competence and professional competence according to [1]. The competences must be fully owned by a teacher, but in fact, the competence and quality of teachers are still not evenly distributed [2]. This is because one of them is the unequal opportunity of teachers to improve their competence through training, either organized by government institutions or other.

[3] revealed the results of his research that the participation in the training was still lacking, even though the participation in seminars and workshops could provide new understanding and knowledge for teachers in improving the quality of learning.

The teacher training that has been carried out through various education quality improvement projects has been ineffective. The training is carried out just to meet the demands of the project [4]. [5] sees that there are two things that have caused the education and training to not be able to provide a major impact on improving teachers' quality. First, education and training is not based on real problems in the classroom (unrealistic class problem). Second, the implementation of the education and training results is not yet complete. The results of the new training in the level of knowledge are not applied in classroom learning. This is due to the content of the education and training material that is too theory-oriented so that it is not applicable or can be due to the absence of post-training monitoring.

The training aims to foster and enhance the skills of science and art, mental or skills needed to fulfill values in life. Through training, the aim is to improve teacher competencies, one of which is to improve the ability to develop practical guides. [6] revealed the weakness of teachers in designing laboratory activities, especially procedural and conceptual knowledge. The existence of these weaknesses resulted in the design of laboratory activities in the field applied to students without prior analysis to be adapted, modified or reconstructed.

[7] found that many teachers experienced difficulties in designing worksheets based on learning models as mandated by the curriculum. Scaffolding type training is a type of effective training program to improve participant competency in developing tests [4].

A. Aspects of teacher ability that can be developed

[8] revealed that there are several aspects that can develop the ability of teachers to design lab work activities, namely (1) determine practical objectives, (2) determine the type, (3) determine the tools and materials, (4) determine the experimental series, (5) self-planning trial procedures, (6) preparing worksheets and (7) designing activity evaluations.

\section{B. Definition of Scaffolding}

Wood, Bruner and Ross who coined the term scaffolding in 1975 based on the concept of zone of proximal development (ZPD) from Vygotsky. Scaffolding is understood as a systematic sequence of requested content, material or tasks and teachers and supporters as optimizing learning, is also understood as a process by which learners are given support so they can apply their new skills and strategies independently [9].

Zone of Proximal Development (ZPD) is an area between what learners can do independently (mastery level) and what 
can be achieved with the help of competent or peer (instructor level) [10].

According to McKenzie in [10] there are six aspects of teaching scaffolding, namely (1) preparing clear directions and reducing learners' confusion, (2) clarifying goals, (3) maintaining learners in their work (4) clarifying goals and expectations and integrating assessment and feedback, (5) showing useful sources to reduce confusion in learners and (6) reducing uncertainty, surprise and disappointment.

\section{Scaffolding training}

The development was carried out by Ellis \& Larkin [4] for the implementation of scaffolding strategies in teacher training through the steps the teacher does, the class does, groups do and individuals do.

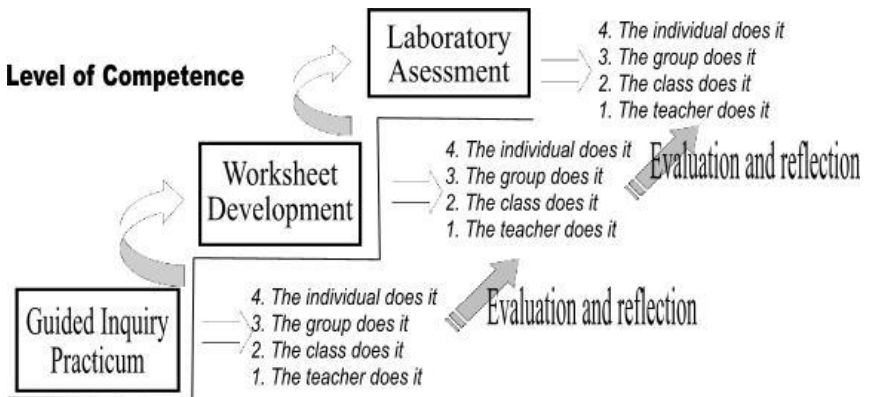

Figure 1: Stages of teacher training adopted by PPGS Jalmo and Rustaman

Scaffolding type training stages according to [4] consist of four steps, they are:

a. The first stage, the coach modeled problem solving steps (the teacher did), not with material explanation. In scaffolding learning, the position of the trainer as the MKO (the more knowledgeable other) is the person who has more competence than the participants. This MKO will develop participants to achieve their potential competencies. The trainer provides the right example of problem solving.

b. The second stage, which is the dummy class. At this stage the responsibility of the trainer is left to the class, the trainer only acts as a companion and collects the opinions of the participants / class. Class work results are evaluated and reflected to control the absorption (understanding) of participants. Work evaluation is intended to find out whether the work has met the specified standards or not. Reflection is needed to correct and correct its deficiencies.

c. The third stage, that is the group does, assignments are given to small groups. Problem solving is done by intensive interaction and communication between group members. Groups that have difficulty can ask for coach assistance. Group work results are evaluated and reflected.

d. The fourth stage is that individuals do. Each participant is given an assignment / problem to be done / solved individually. In this final step the participants are required to be more independent to demonstrate the completion of their tasks. The ability of participants to complete the task at this stage illustrates the competency of participants has increased from before.
This study aims to develop effective training for teachers in improving the ability to create guided inquiry lab worksheets. The main problem in this study is "How is the effectiveness of teacher training in the development of guided inquiry lab work worksheets?".

Literally, training is defined as "giving lessons and practice", "making it develop in the desired direction". There are many meanings about training, as expressed by [11], [12], [13], [14], [15], [16], thus, training can be interpreted as an effort to improve a certain competence in a scientific subject within a certain period of time.

[17] states that student worksheets (LKS) are sheets that contain tasks that student must do and contain instructions, steps that must be taken to complete the task in the form of theory and practice. According to [18] worksheet is a guide for students used for investigation or problem solving activities. Student worksheets can be in the form of guidelines for developing cognitive aspects as well as guidance for developing all aspects of learning in the form of an experimental guide or demonstration. Because worksheets are guidelines for educators in carrying out learning activities and assignments to students, the compiled LKS must meet didactic requirements, construction requirements and technical requirements [19].

\section{METHOD}

The subjects of this study were teachers who were members of the Chemistry teachers MGMP in Karawang Regency, totaling 26 people as training participants conducted in scaffolding. Mixed methods are chosen because there is a need to study more in the qualitative and quantitative aspects. Because this study aims to get effective training, this study uses a case study design. According to [20] case study design is a research that is directed to collect data, take meaning, gain an understanding of the case, by only exploring one phenomenon and ignoring other phenomena. To measure the quantitative side, the pre-experimental method (pre-experimental design) was employed [21].

In addition, the researchers intervened throughout the study with the One-group pre-test-post-test Design that is a study designed by involving one group given pre-test $(\mathrm{O} 1)$, treatment (X) and post-test $(\mathrm{O} 2)$ [22] and questionnaire distribution to see teacher responses to training. Pre-test and post-test results were calculated by measuring N-gain from [23] and scoring the teacher's response to the training of [24]. The qualitative side is characterizing the training worksheet

\section{RESULT AND DISCUSSION}

In general, this study involved a number of chemistry teachers to be given training in scaffolding to improve the ability of teachers in the development of lab work guidelines. As a prerequisite for training, the teachers were asked to collect worksheets / lab work guides that are commonly used for certain materials that would be characterized, at the beginning of the training were given the pre-test and at the end of the training were given post-test and questionnaire to measure the success of the training. 
In Figure 2 below, the flow of training activities is carried out through three stages, namely pre-training, training and post-training. In the pre-training, the participants submitted the lab work worksheets that they used to use in the learning process. At the time of the training, the participants received the material by scaffolding with certain stages (the teacher did the class to do the do-individual group) until the training ended. And finally, after the training participants were asked to submit guided inquiry worksheets products for certain materials, conducted questionnaires about training and were given posttest.

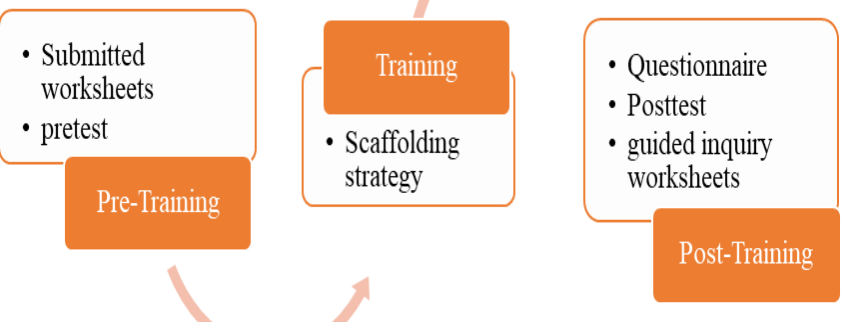

Figure 2: Teacher Training Design

Before training, the participants were asked to collect practical worksheets that were used in the concept of reaction rates. Presented in table 1 below

TABLE I SOURCE AND CHARACTERISTICS OF PARTICIPANTS' WORKSHEETS

\begin{tabular}{|c|c|c|c|}
\hline \multicolumn{2}{|c|}{ Source of Worksheet } & \multicolumn{2}{c|}{ Characteristic of Worksheet } \\
\hline Producer & Percent & Type & Percent \\
\hline Personal & 35 & Confirmation & $88 \%$ \\
\hline Others & 65 & Guided inquiry & $8 \%$ \\
\hline- & - & Authentic inquiry & $4 \%$ \\
\hline Score & $\mathbf{1 0 0}$ & & $\mathbf{1 0 0}$ \\
\hline
\end{tabular}

[25] found the fact that many teachers experienced difficulties in designing worksheets as mandated by the 2013 curriculum. In addition, [26] reported that teachers rarely make their own worksheets, they use worksheets already in the book, instead. Worksheet is a good learning media and needs to be made in accordance with the characteristics of students, materials and available facilities.

The number of confirmation worksheets used by prospective trainee teachers is similar to what Rahmawati et al said [27] so far the lab work carried out in schools is still verification which is only proving the concepts or principles that have been learned. [28] the consideration of the teacher using verification LKS in the form of a cookbook (recipe book) is easy to use by students even though it has some weaknesses such as too much guiding students when students carry out lab work activities in the laboratory. After the training, the participants designed a lab work guide with guided inquiry characteristics and included contextual phenomena of the effect of vinegar acid concentration when reacted with baking soda and designed a lab work guide on the effect of fertilizer concentration on grain sprout growth.
TABLE II. TEACHERS' RESPONSES TO TRAINING

\begin{tabular}{|c|c|c|c|}
\hline No & Topic & Average & Category \\
\hline 1 & Training materials & 79 & Strong \\
\hline 2 & Training activities & 80 & Strong \\
\hline 3 & Practical draft & 81 & Very Strong \\
\hline 4 & Lab work assessment & 88 & Very Strong \\
\hline 5 & Follow-up training & 85 & Very Strong \\
\hline
\end{tabular}

As shown in Table 2, the material that received the best response was the practical evaluation design material. A strong response from the trainees is a valuable asset for the success of the training. someone who has strong beliefs and motivations will have confidence in the work or other challenges in his life.

Analysis of the pre-test and post test scores of teachers' understanding in designing guided inquiry lab worksheets have increased. The increase is shown by the N-gain obtained by the trainees. The average $\mathrm{N}$-gain of training participants is 0.71 with the medium category. Distribution of trainee $\mathrm{N}$-gain is shown in table 3 below.

TABLE III. N-GAIN DISTRIBUTION BASED ON CATEGORIES

\begin{tabular}{|c|c|c|c|}
\hline \multirow{2}{*}{ Unit } & \multicolumn{3}{|c|}{ Category } \\
\cline { 2 - 4 } & High & Medium & Low \\
\hline Score & 13 & 11 & 2 \\
\hline Percentage & $50 \%$ & $42 \%$ & $8 \%$ \\
\hline
\end{tabular}

From the table above, there are two participants who have a low $\mathrm{N}$-gain with fairly high pre-test and post-test scores. Ngain only gives a picture of changes or increases in the results of the intervention, the greater the $\mathrm{N}$-gain, the more positive changes obtained by the trainees. The smaller the N-gain, does not show the inability of participants in participating in the training. Overall, the training has a strong enough impact on the teacher's ability to design practical guide material for reaction rates. [29] states that the ability of teachers to design inquiry-based lab works has increased after participating in training in the type of scaffolding.

Based on the picture below, the aspect of analyzing the curriculum has the smallest $\mathrm{N}$-gain value while the aspect of compiling the steering questions and aspects of presenting experimental data in the form of tables / graphs. [30] revealed that curriculum analysis is the first thing a teacher must do in designing a lab work or learning process. In the activity of analyzing the curriculum, a teacher must analyze the needs in accordance with the curriculum while the aspect of presenting data in table form increases because at the time of training was given training in making graphics / tables using Microsoft Excel program. 


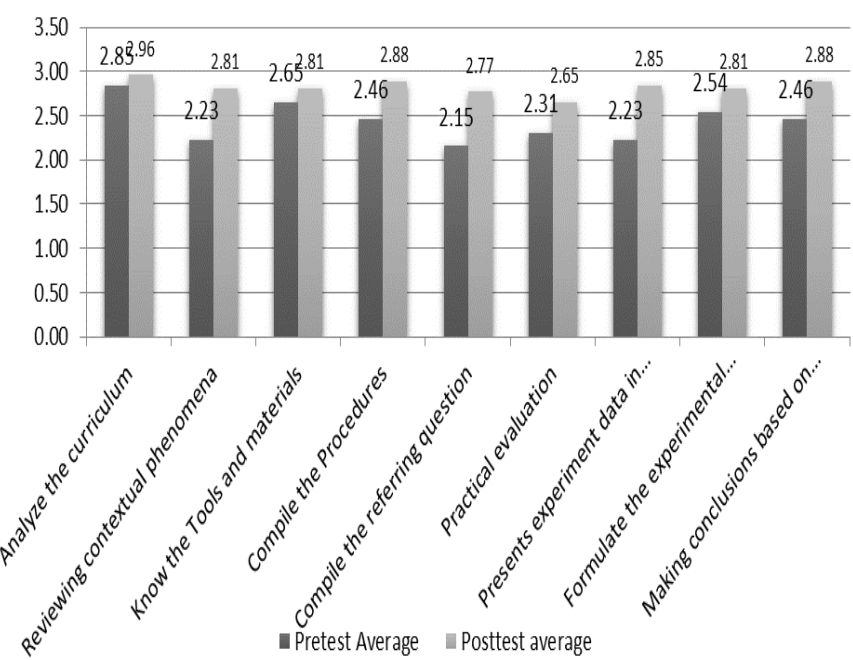

Figure 3: Histogram comparisons of pre-test and post-test mean scores in designing guided inquiry-based lab work per indicator

\section{CONCLUSION}

The results achieved in this study indicate that the teacher's response to training materials and training methods is very strong based on the results of the pre-test and post-test. Of the five aspects of training that were given responses, three of them gave very strong responses, with an average response score of 82.6. The ability of teachers to improve is categorized as medium with an $\mathrm{N}$-gain value of 0.71 . In general, the teacher's response to the training showed a very positive response especially to the topic of practical evaluation or evaluation. Some teachers demonstrated their ability to design guided inquiry-based lab worksheets mainly related to contextual phenomena, including the effect of vinegar acid concentration on baking soda decomposition reactions, and the effect of fertilizer concentrations on grain sprout growth. The development of the teacher's ability through measurable training and focusing on improving teacher competencies must be done frequently, the selection of materials that are needed and used in the learning process must also be considered.

\section{REFERENCES}

[1] Kemendikbud, Peraturan Pemerintah Republik Indonesia No 19 Tahun 2005 tentang Standar pendidikan Nasional, Jakarta: Kemendikbud, 2005.

[2] A. Alhumami, "Pelatihan Guru Harus Rutin", (http://nasional.kompas.com/read/ 2016/08/13/16371671/ pelatihan.guru.harus.rutin.dan.merata), 2016

[3] F. Kawuwung, F, "Profil Guru, Pemahaman Kooperatif NHT dan Kemampuan Berpikir Tingkat Tinggi di SMP Kabupaten Minahasa Utara", El-Hayah. vol. 1, pp. 157-166, 2011.

[4] T. Jalmo and N. Y. Rustaman, "Pengembangan program pelatihan peningkatan kompetensi guru IPA SMP”, Forum Pendidikan, Vol. 30, no. 1, pp. 79-88, 2010

[5] I. Pulungan, Analisis kompetensi guru pascadiklat guru matapelajaran kimia tingkat madrasah aliyah se Sumatera Utara, Medan: BDK Medan , 2013.

[6] B. Supriatno, engembangan program perkuliahan pengembangan praktikum biologi sekolah berbasis ANCORB untuk mengembangkan kemampuan merancang dan mengembangkan desain kegiatan laboratorium, Disertasi. Bandung: UPI, 2013.

[7] S. Haryani, S. Wardani, and S.T. Prasetya, "Analisis Kemampuan Penyusunan Lembar Kerja Siswa Berbasis Problem Based Learning dan Project Based Learning”, Jurnal Inovasi Pendidikan Kimia, Vol. 12, No. 1, pp. 2086-2096, 2018

[8] Wiyanto, Pengembangan Kemampuan Merancang dan Melakukan Kegiatan Laboratorium Fisika Berbasis Inkuiri Bagi Mahasiswa Calon Guru, Disertasi Doktor SPs UPI Bandung : Tidak diterbitkan, 2005.

[9] M. Larkin, Using Scaffolded Instruction To Optimize Learning, ERIC Digest, 2002.

[10] R. R. Stuyf, "Scaffolding as a Teaching Strategy", 2017

[11] D. Sudjana, Sistem dan Manajemen Pelatihan, Bandung: Falah, 2007

[12] D. Darmawan, Efektivitas pelatihan kecakapan vokasional dalam meningkatkan kompetensi kerja (studi deskriptif pada peserta life skill di PKBM Wilayah DKI Jakarta), Disertasi. Bandung: Sekolah Pasca Sarjana UPI, 2016.

[13] S. Khomsatun, Efektiftas workshop achievement motivation training (AMT) dan peer teaching terhadap peningkatan kompetensi pengelolaan pembelajaran, Tesis. Program Pascasarjana: STAIN Salatiga, 2013.

[14] I. Dekawati, "Manajenem Pengembangan Guru”, Cakrawala Pendidikan. Vol. 30, No. 2, pp. 203-215, 2011.

[15] D. Sparks and S. L. Horsley, "Five models of staff development", Journal of Staff Development, pp. 1-28, 1989.

[16] M. Kamil, Model Pendidikan dan Pelatihan, Bandung: Alfabeta, 2012.

[17] Depdiknas, Pedoman memilih menyusun bahan ajar dan teks mata pelajaran, Jakarta: CV. Mini Jaya Abadi, 2007.

[18] M. Trianto, Mendesain Model Pembelajaran Inovatif-Progresif (Konsep, Landasan dan Implementasinya pada Kurikulum Tingkat Satuan Pendidikan KTSP), Jakarta: Kencana, 2012.

[19] H. Darmodjo and J. R. Kaligis, Pendidikan IPA II, Jakarta: Depdikbud, 1992.

[20] N. S. Sukmadinata, Metode Penelitian Pendidikan, Bandung: Remaja Rosda Karya, 2015.

[21] Sugiyono, Metode penelitian kuantitatif, kualitatif dan R\&D, Bandung: Alfabeta, 2014.

[22] J. H., Mc.Millan, and S. Schumacher, Research in Education: a Conceptual Introduction, New York: Longman, 1997.

[23] R. R. Hake, "Analyzing Change-Gain”, (http://www. physics. indiana. edu/ sdi/AnalyzingChange-Gain. pdf ), 1999.

[24] S. Haryani, S. Wardani, A. T. Prasetya, Analisis kemampuan penyusunan lembar kerja siswa berbasis problem based learning dan project based learning. Jurnal Inovasi Pendidikan. Vol 12, 2086-2096

[25] S. Haryani, S. Wardani, A. T. Prasetya, Analisis kemampuan penyusunan lembar kerja siswa berbasis problem based learning dan project based learning. Jurnal Inovasi Pendidikan. Vol 12, 2086-2096

[26] P. B. Andyana, D. M. Citrawathi, and I. M. Santiasa, Pelatihan pembuatan LKS Inkuiri berbasis pertanyaan untuk materi biologi bagi guru-guru IPA SMP Kota Singaraja, Singaraja: FMIPA Universitas Pendidikan Ganesha, 2017.

[27] U. F. Arifin, S. Hadisaputro, and E. Susilaningsih, "Pengembangan lembar kerja praktikum siswa terintegrasi guided inquiry untuk keterampilan proses sains", Chemistry in Education, pp. 54-60, 2015.

[28] G. Dwiyanti, A. Suryatna, R. A, Wiguna, and F. Alifiani, "Optimasi prosedur percobaan dan penyiapan lembar kerja siswa sebagai perangkat pembelajaran identifikasi unsur karbon dan hidrogen dengan model inkuiri terbimbing", Seminar Nasional Kimia dan Pendidikan Kimia VII, pp. 1-10, 2015.

[29] A. I. Gumilar, Pengembangan kemampuan guru kimia dalam merancang praktikum berbasis inkuiri melalui pelatihan guru tupe scaffolding untuk meningkatkan kreativitas siswa, Tesis. Tidak diterbitkan: Sekolah Pasca Sarjana. UPI, 2016.

[30] M. Arifin, Pengembangan Kurikulum dan Pembelajaran Kimia, Jakarta: Universitas Terbuka, 2007. 